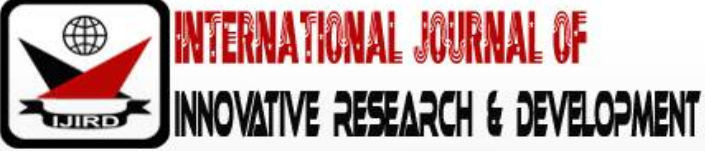

ISSN 2278 - 0211 (Online)

\section{Micro- Finance and Poverty Alleviation of Rural Agricultural Households in the Hohoe Municipality, Ghana}

\author{
Kafu George Yao \\ Tutor, Department of Social Science, Peki Senior High School, Ghana
}

\begin{abstract}
:
Even though great progress has been made towards achieving the Millennium Development Goals by reducing poverty, people continue to live in extreme poverty and more than two thirds of the world poor reside in rural areas. As a result, spatial inequality in development still exists between rural and urban areas due to lack of economic growth and effective policies for rural development. In order to examine microfinance and poverty alleviation in the Hohoe Municipality, the study employed economic and social variables as benchmarks for measuring the impact of microfinance. A total of 150 respondents were sampled. On the material possession of the respondents, it was clearly observed that both beneficiaries and non-beneficiaries of microfinance are not able to acquire expensive commodities but only the basic necessities of life. However, the study discovers that microfinance can help agricultural households to invest in their own businesses, educate their children, and promote their overall well-being. This study recommends among other things that MFIs should design appropriate products that are flexible enough to meet the different needs of rural agricultural households for both production and consumption purposes. It is hoped that the study will serve as a 'spring board' for further studies and thus provide the necessary information needed for financing rural agriculture in the Hohoe Municipality.
\end{abstract}

Keywords: Microfinance, poverty alleviation, agricultural households

\section{Introduction}

There is a consensus in literature that poverty is a rural phenomenon as most rural dwellers still have no access to food, shelter, infrastructure, good healthcare and education (Fields 2000 and Yankson 2008). While the rural population, still harbour a large proportion of the world's population, specifically, 3.1 billion or $55 \%$ of the world's population, the rural development policy focus on rural development are still minimal compared to that of urban development (Alderman \& Paxson 2010). Spatial inequality still exists between rural and urban populations, because economic growth and policies for rural development remains a challenge for the international community (Botchie, \& Ahadzie, 2004, WHO 2008).

Statistics by the Human Development Index (2009) showed that extreme poverty in Sub - Saharan Africa has doubled from 205 million in 1981 to414 million in 2010. According to Yaro (2013), rural Africa is still confronted with latent economic and structural challenges such as poor use of technology, low infrastructural development and low level of productivity due to the subsistent nature of agricultural livelihoods.

The situation in Ghana is no different as research has proved that poverty is still pervasive, and that $24.3 \%$ of Ghana's population lives below the poverty line (Bank of Ghana 2015, GSS 2010 \& 2008, Owusu, 2007). Regrettably, majority of these people live in the rural areas where about $80 \%$ of food crops are produced, yet their incomes are insufficient for adequate diet due to subsistence agriculture (Alderman and Paxson 2010 and Wodon 2008).

For this reason, poverty reduction has become paramount in the development discourse and it is based on this that it is the number one of the eight Millennium Development Goals (MDG). In this regard, successive governments in Ghana have undertaken a number of development interventions to reduce poverty among its citizenry. For example, Free Compulsory Basic Education (FCUBE), School Feeding Programmes, Economic Recovery Programme (ERP), Structural Adjustment Programmes (SAP) and Women in Development Fund (WDF). Notwithstanding these policy interventions, the Ghana Poverty Reduction Strategy (GPRS) I \& II $(2003,2006)$ noted that there is uneven decline in poverty reduction and incidents of growing poverty in some geographical areas. The evidence suggests that the vulnerability and exclusion among some geographical groups, socio-economic groups, gender and age groups may have worsened. Thus, a lot more still needs to be done to achieve the goal of poverty reduction.

To achieve equitable poverty reduction, access to income is vital for the development of private and informal sectors of the national economy. According to Sundaresan (2008) access to basic financial services (such as credit, saving and insurance), can develop the entrepreneurial skills of the poor who are currently outside the perimeters of the mainstream financial services.

The emergence of microfinance scheme is considered as one of the most effective and flexible strategies in the fight against global poverty. Scholars such as (Barrett et al., 2006 and Berg 2010) argued that the scheme provides 
participatory and bottom-up approach to poverty reduction that can address the economic, social and political needs of the poor who are engaged in entrepreneurial activities in the informal economy. This assumption of the benefits of microfinance has led to significant public and private sectors investment into microfinance schemes which are made available to the poor. For the purpose of this research, microfinance is regarded as financial services such as loans and savings to low-income groups for immediate family expenditure like food, clothing and shelter to reduce the impact of economic of economic shocks and increase their assets.

A survey by the Ghana Statistical Service in 2008 revealed that Hohoe Municipality in the Volta Region has a large rural population of $80 \%$ who depend mainly on agriculture. The incidence of poverty is largely felt in the rural areas and within the Agricultural Sector and for this reason, the Municipality faces huge problem in alleviating poverty (GHAMFIN, 2003). Since microfinance has achieved some accomplishments over the last 10 years among petty traders and even government workers in the Hohoe Municipality, this research strongly advocate for microfinance as a means of alleviating poverty among rural agricultural households in the Municipality. The study therefore takes a critical look at the Geography of the rural poor.

\subsection{Objectives of the Study}

The main objective of this study is to assess the contributions of microfinance and poverty alleviation in rural agricultural households in the Hohoe Municipality.

The specific objectives include the following:

I. To evaluate the extent to which Microfinance Institutions (MFIs) have assisted rural agricultural households to improve their standard of living.

II. To identify constraints associated with the delivery of micro credit by Microfinance Institutions (MFIs).

\subsection{Literature Review}

There is a burgeoning literature about the nexus between microfinance and poverty reduction in rural communities. While others like Sowa (2008) considers microfinance as a potent tool for poverty reduction, critics on the other hand contend that microfinance could even make the poor worse off.Proponents of microfinance argue that small loans to poor people could serve as a powerful tool for alleviating poverty (Adjei, 2010; Coleman, 2002, Richard, 2007).

This is consistent with the UNCDF (2009) claim that microcredit for small farmers provides a means for expanding economic opportunities and reducing the vulnerability of the rural poor.Gender activists also argue in favour of microfinance as a means of empowerment by supporting women`s economic participation (Muscoda, 2006 \& Littlefield, 2005). This is also supported by a study conducted by Kharlan and Zinman (2006) in South Africa where recipients of microcredit were shown to be better off than non-beneficiaries.

However, other studies contend that, the impact of microfinance has been over advertised or hyped (Ditcher, 2006 \&Karikari, 2009). For example Buckley (1997) and Rogaly (1996) argue that, microfinance may not always be the best tool to help the poorest of the poor. This was confirmed by Ditcher (2006) that the best way to alleviate poverty is to create jobs and increase worker productivity but not through microcredit.

\subsection{Gab in Knowledge}

Even though much work has been done on microfinance and poverty alleviation, focus on agricultural lending has been less. Moreover, for further understanding of the social impact of micro-finance on rural farmers, critical questions need to be asked, especially contribution to various facets of farmers' lives and whether the current arrangement is viable and for which could be a basis for its sustenance. The current study seeks to interrogate these issues using Hohoe as a case study. The use of this municipality is hardly fortuitous because it has a huge rural population who are directly engaged in agriculture and also requires capital to expand their business. So this can make a valuable contribution to literature.

\subsection{Description of the Study Area}

Hohoe Municipality is located in the centre of the Volta Region. It was created in 1979. Quoting from the analytical report of the 2010 population census by the Ghana Statistical Service, "Hohoe Municipality has a total land area of 1,172 $\mathrm{km} 2$, which is 5.6 percent of the land area of the Volta region. It is located on longitude $0^{\circ} 15^{\prime} \mathrm{E}$ and $0^{\circ} 45^{\prime} \mathrm{E}$ and latitude $6^{\circ}$ $45^{\prime} \mathrm{N}$ and $7^{\circ} 15^{\prime} \mathrm{N}$ and lies almost in the heart of the region. It shares borders with the Republic of Togo on the east, forming part of Ghana's international border; on the southeast by the Afadzato district and southwest by Kpando Municipality; on the north with Jasikan district; and on the northwest with the Biakoye districts. Its capital, Hohoe, is about $78 \mathrm{~km}$ from Ho, the regional capital and $220 \mathrm{~km}$ from Accra, the national capital". Being a semi- deciduous forest, crops such as maize, cassava, rice and plantain are produced. Generally, large-scale farming activities are limited in the area. Agriculture in the Municipality especially the rural areas are on subsistence level, and very few farmers engage in plantation farming. Due to this poverty is common in the rural component of the Municipality. Figure 1 is the map of the study area. 


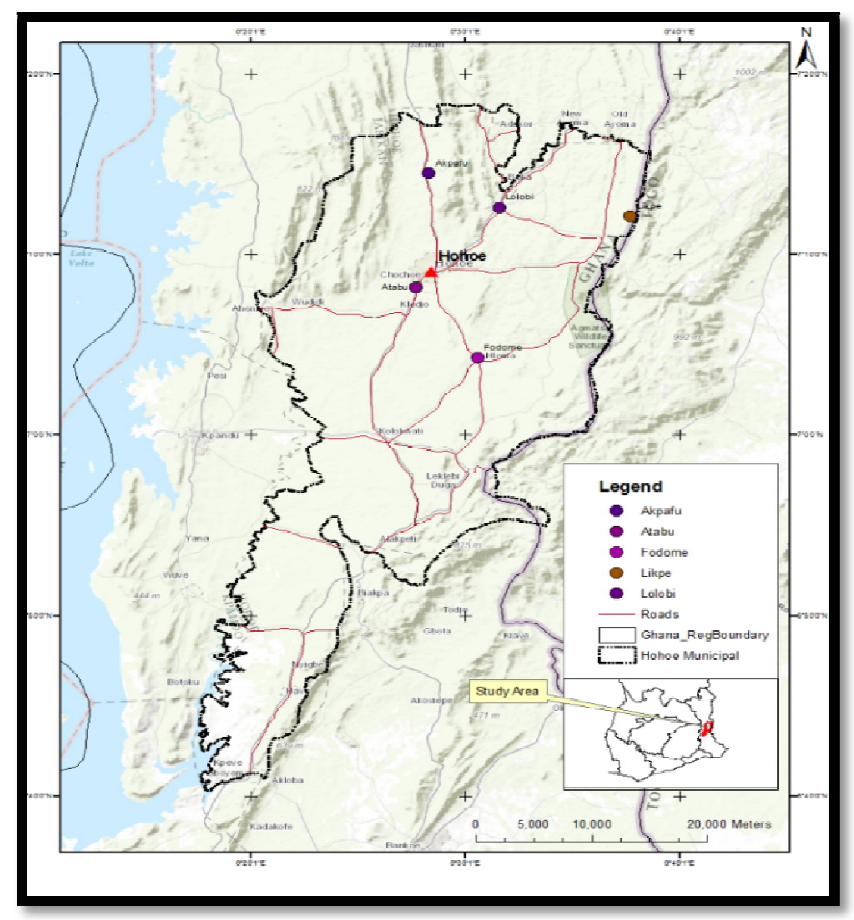

Figure 1: Map of the Study Area

\subsection{Materials and Methods}

The study adopted a mixed method approach. According to Creswell (2009), the mixed method approach combines both quantitative and qualitative forms. In this study, the survey was first conducted (i.e. quantitative).Followed by across-sectional survey which was used to assess the experiences of micro-finance activities on beneficiaries and challenges faced in accessing loans.

Data was obtained from questionnaires administered to 150 respondents selected from 20 farmer groups and structured interview for both officials and beneficiaries of microfinance

With regards to the qualitative results a face to face interview was conducted for 6 officials of microfinance. This comprises of two officials each from MASLOC, CRAN and Universe Co-operative Society. Finally to elicit views and opinions from the participants, qualitative audio in the form of tape recording and mobile phone interview was conducted for 15 beneficiaries and 5 non beneficiaries.

In terms of sampling, a stratified sampling procedure was used in sampling the respondents for the study because of the heterogeneous nature of the population. The main reason is that two groups were involved that is beneficiaries and non beneficiaries of microfinance.

The choice of the sample size was based on $+/-5 \%$ precision level and confidence interval of 95\% (Yamane, 1967). In terms of specific sample of the two strata, a total of 110 constituted the sample for the beneficiaries, whiles 40 constituted the sample for the non-beneficiaries to serve as a control group. It must be emphasized that the respondents were mainly farmers hence a homogeneous group and stratification was disproportionate as indicated earlier.

Statistical Package for Social Sciences (SPSS) for windows version 20.0 software was used to conduct the analysis. An independent sample T-test (non-parametric) was conducted to examine whether there were statistically significant differences in poverty level between beneficiaries and non-beneficiaries. The qualitative data was analysed manually without using any software. The evidences were presented in narrative to complement findings from the quantitative data in the form of direct quotes through the use of an integrated mixed method analysis (Joanna, 2014).

\section{Results and Discussion}

This chapter presents the results and discussion of the study. In addition, the results are presented in sections with each section addressing an objective. Both the quantitative and qualitative results are integrated to offer a better understanding of the issues.

\subsection{Differences in Poverty between Beneficiaries and Non-Beneficiaries (Independent Sample T-test)}

Table 1 is an independent sample T-test result. The dependent variables (DV) included average income, daily expenditure, fraction of income into food and expenditure on wards education. The independent variable was whether one has gone for a bank loan before with response Yes or No. To satisfy the condition for this test, a Levene Test for equality of variance was performed. None of the dependent variables had a significant score of 0.5 , the lowest was 0.14 , (Test not presented) i.e. expenditure on wards education. That is to say the variance of going for a loan or not going for a loan is approximately equal.

Findings on the expenditure on children education shows that non-beneficiaries spent much higher compared to the beneficiaries. Again, the SD was very high, meaning there is a much spread of earning for the two categories. Can we therefore conclude that Microfinance is not bringing any improvement in the well-being of beneficiaries? An answer to this 
must consider other factors such as size of loan, cost of employing other productive inputs and other loan arrangements.Discussion on some of these issues will aid understanding of these issues.

\begin{tabular}{|c|c|c|c|c|c|c|}
\hline DV & IV & N & Mean & SD & Df & Sig. \\
\hline Average income & Yes & 110 & 293.76 & 286.76 & 148 & .029 \\
\hline No & 40 & 407.33 & 606.35 & 14 & \\
\hline Daily expenditure & Yes & 110 & 10.80 & 7.30 & 147 & .386 \\
\hline $\begin{array}{c}\text { Fraction of income } \\
\text { into food }\end{array}$ & No & 40 & 9.13 & 3.82 & 27.34 & \\
\hline $\begin{array}{c}\text { Expense on children's } \\
\text { education }\end{array}$ & No & 110 & 64.27 & 12.47 & 145 & .145 \\
\hline & Yes & 98 & 146.53 & 202.17 & 106 & .014 \\
\hline
\end{tabular}

Table 1: Differences in Poverty between Beneficiaries and

Non-Beneficiaries (Independent Sample T-Test).

Source: Field Survey, 2015

\subsection{Socio-Economic Impact of Credit on Agricultural Households}

From Table 2, 82 out of 110 respondents representing (74.8\%) responded that they could pay their children's school fees with microcredit while $28(25.2 \%)$ could not provide or send their children to school after accessing the credit facilities from MFIs. The responses on health related issues are not very different from that of education. While $71.1 \%$ could pay their hospital bills, $28.1 \%$ reported that they could not pay their bills after receiving the credit. In terms of feeding, 88\% agreed that microcredit helped them to feed their families but about $12 \%$ could feed their families even after accessing the loans.

On the issue of utility, $71 \%$ of beneficiaries are able to pay their electricity bills while $28.9 \%$ of the respondents indicated that they could not pay their bills. About payment of funeral expenses, 56 respondents representing 51.1 percent answered Yes whilst 48.8 percent said No.An important observation through the face to face interview was that, during bereavement, some of the farmers invested so much into funerals, hoping to get donations from sympathizers during the funeral ceremony. However, when this expectation is not met, the farmers become more impoverished. The quote below from one assemblyman illustrates this point.

"We regard funerals as appropriate occasions to raise funds for suitable ventures. But if this goal is thwarted, we come back to square one. Unfortunately this has been the experience of some of our community members over the years especially the peasant farmers."

Finally, with regards to building and rehabilitation of houses, majority of respondents indicated that proceeds from microfinance could not help them to improve their houses like painting them.

Overall, when asked whether receiving credit has improved their standard of living or not, majority of the respondents confirmed that micro credits had a positive impact on their lives. Based on the results, this study argues that microfinance can assist the poor by improving their standards of living. As pointed out during the launch of the International Year of Micro Credit (2003);

"Sustainable access to microfinance helps alleviate poverty by generating income, creating jobs, allowing children to go to school, enabling families to obtain health care, and empowering people to make the choices that best serve their needs." (Kofi Annan, December 2003).

\begin{tabular}{|c|c|c|c|}
\hline Social Impact of MF on Households & Category & Freq & $\mathbf{\%}$ \\
\hline Payment of children's school fees & Yes & 82 & 74.8 \\
\hline Payment of hospital bills & No & 28 & 25.2 \\
\hline & Yes & 79 & 71.9 \\
\hline Able to feed family & No & 31 & 28.1 \\
\hline & Yes & 97 & 88.1 \\
\hline Payment of electricity bills & No & 13 & 11.9 \\
\hline & Yes & 78 & 71.1 \\
\hline Payment of funeral expense & No & 32 & 28.9 \\
\hline & Yes & 56 & 51.1 \\
\hline Ability to rehabilitate oldbuilding & No & 54 & 48.9 \\
\hline & Yes & 45 & 40.7 \\
\hline
\end{tabular}

Table 2: Socio-Economic Impact of Credit Access on Households

Source: Field Survey, 2015

\subsection{Economic Impact of Microfinance on Beneficiaries.}

To evaluate the impact of microfinance on business level of beneficiaries, results indicated that micro credit had a positive impact on the farming enterprises of beneficiaries because the maximum income obtained before the loan 
was GHC 1600.00 but after the loan, income increased to GHC 5000.00. Table 4.12 also analyzed employment level of beneficiaries first, before access to micro- credit and second, after about three years into having access to microfinance opportunities. The data shown in Table 4.12 revealed that microfinance has not helped in the expansion of their businesses. The results indicated that before the loan they could only employ 10 workers but after the loan only 12 workers were employed. A corroborative evidence concerning impact of loan on business was found in a study by Taiwo's (2012) in South Eastern Nigeria. He also found that 91\% of the respondents agreed that micro finance has helped in the expansion of business through the availability of facilities such as savings, loans, overdraft, etc at affordable rates.

\begin{tabular}{|c|c|c|c|c|c|}
\hline Business Expansion Variables & N & Min & Max & Mean & SD \\
\hline Revenue obtained before the loans & 134 & 0 & 1600 & 317.24 & 21.72 \\
\hline Revenue obtained(5 years) after the loan & 133 & 80 & 5000 & 687.67 & 61.95 \\
\hline Number of people employed before the loan & 129 & 0 & 10 & 1.95 & 1.54 \\
\hline $\begin{array}{c}\text { Number of people employed as wage } \\
\text { employees after the loan }\end{array}$ & 133 & 0 & 12 & 3.36 & 2.25 \\
\hline
\end{tabular}

Table 3: Micro-Finance and Expansion of Business

Source: Field Survey, 2015

\subsection{Constraints Associated with the Delivery of Micro Credit by Microfinance Institutions (Mfis)}

Table 4.13 shows a rating of the constraints most farmers faced with when accessing loans from the financial institutions. The results revealed that about $52 \%$ of respondents rated interest rate as a very major constraints influencing access to micro loans. This was followed by lack of collateral (34.1\%), then loan size (23\%), Bureaucracy in the processing of credit (20.7\%), availability of guarantor (19.3\%), group lending required (14.8), untimely delivery of credit ( $14.1 \%$ ) and finally $10.4 \%$ of rating for credit being tied to certain ration of savings.

\begin{tabular}{|c|c|c|c|c|c|c|}
\hline \multirow{2}{*}{ Constraints of Microcredit Access } & \multicolumn{5}{|c|}{ Rating of Constraints Faced in Accessing Credit } \\
\cline { 2 - 7 } & 1 & 2 & 3 & 4 & 5 & Total (135) \\
\hline Lack of sufficient collateral & 34.1 & 37.0 & 5.9 & 4.4 & - & 81.5 \\
\hline Availability of guarantor & 19.3 & 40.0 & 19.3 & 2.2 & .7 & 81.5 \\
\hline Interest rate & 51.9 & 21.5 & 3.7 & 4.4 & - & 81.5 \\
\hline Loan size & 23.0 & 34.1 & 17.8 & 5.9 & .7 & 81.5 \\
\hline Credit is tied to certain ration of savings & 10.4 & 34.8 & 31.1 & 5.2 & - & 81.5 \\
\hline Group lending required & 14.8 & 28.9 & 24.4 & 9.6 & 3.7 & 81.5 \\
\hline Bureaucracy in the processing of credit & 20.7 & 25.2 & 23.0 & 11.9 & .7 & 81.5 \\
\hline Untimely delivery of credit & 14.1 & 38.5 & 18.5 & 6.7 & 3.0 & 80.7 \\
\hline
\end{tabular}

Table 4: Constraints Associated with Access to Credit

Source: Field Survey, 2015

$1=$ very major constraint $2=$ major constraints $3=$ somehow a constraints $4=$ minor constraints $5=$ very minor constraint.

\subsection{Constraints of Accessing Microfinance by Beneficiaries}

Moreover, as a way of assessing constraints face by beneficiaries, a likert scale measure of how easy or difficult it was accessing loan was used. From Figure 2, about 21.5\% of the respondents responded it was not easy assessing loans from MFI. 32.6\% people responded that it was less easy assessing loans, while 3\% responded that it was very easy assessing loans. The findings show clearly that it is not easy for beneficiaries to access loans. This is due to a multiplicity of factors, particularly loan sizes and interest charges.

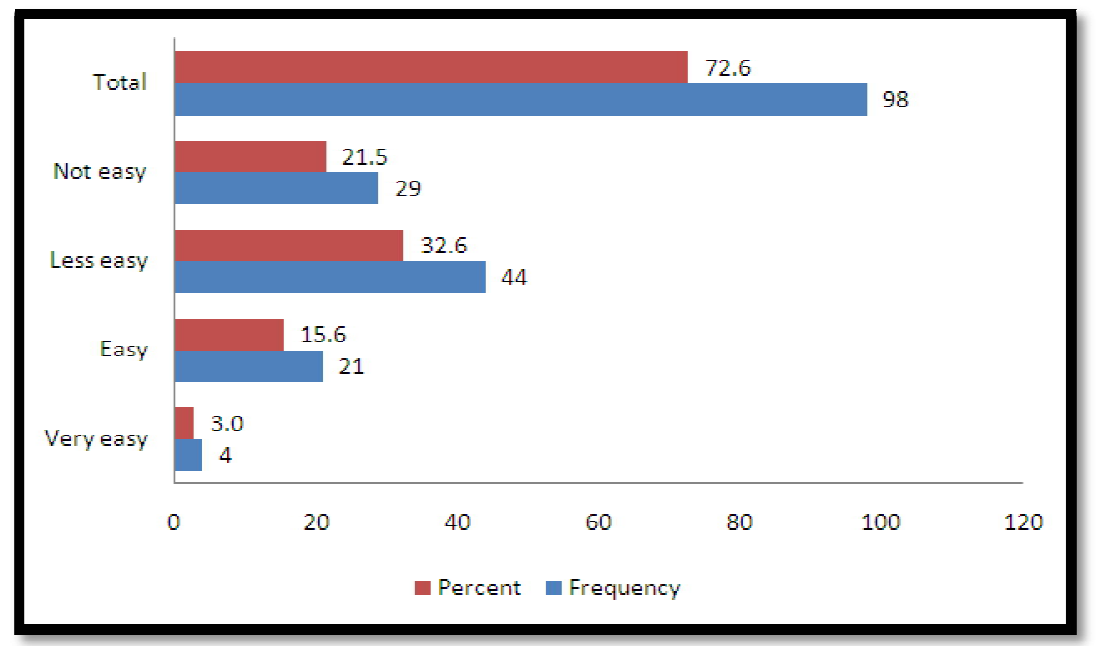

Figure 2: Constraints of Accessing Microfinance by Beneficiaries Source: Field Survey, 2015 


\subsection{Conclusions and Recommendations.}

It is clear that access to financial services is imperative for the development of the informal sector and also helps to mop up the excess liquidity through savings that can be made available as capital investment for the development of rural areas.

The study indicates that the microfinance is unable to reduce poverty to the barest minimum because it adopts just a single approach for the eradication of poverty which is by granting loans. But based on the fact that micro-credit has helped rural agricultural households in the Hohoe Municipality to expand their agricultural enterprises, it is reasonable to conclude that microfinance is a good means of assisting rural poor to small and marginal enterprises. It is therefore regarded as a powerful tool to raise the living standards of the poor when managed properly. Recommendations from this research include:

- Microfinance institutions need to build their staff technical and skill capacity in microfinance through systematic training.

- Microfinance Institutions (MFIs) need to educate their customers about the proper use of microcredit by encouraging beneficiaries to use the credit for the intended purpose

- MFIs should design appropriate products that are flexible enough to meet the different needs of rural agricultural households for both production and consumption purposes

- It is also recommended that the Bank of Ghana in collaboration with the ARB to Apex Bank Limited to ensure proper supervision in order to streamline the activities of MFIs.

\section{References}

i. Adjei, J. (2010). Microfinance and Poverty Reduction: The Ghanaian Experience. Accra: Bold Communication Ltd.

ii. Alderman, H. A. (2010). Do the Poor Insure? A Synthesis of the Literature. World Banking Working Paper WP1008. Retrieved on December 6th 2014 from World Bank Working: Paper WP1008. Available online @ http:/ / ideas.repec.org/ p/ wbk/ vbrwps/ 100

iii. Bank of Ghana (2015). List of Financial Houses in Ghana. BoG Press, Accra.

iv. Barret, H.C, and Bolyanatz, A. (2006). Gender, time use and poverty in Sub - Saharan Africa. Washington, D. C.: The World Bank.

v. Buckley, J. (1997). Impact assessment methodologies for microfinance: theories, experience and better practice. Manchester, UK: University Publication.

vi. (2007). Building durable rural financial markets in Africa.

vii. Botchie, G. and Ahadzie, W. (2004). Poverty reduction efforts in Ghana: The skills development option. Accra, University of Ghana Press.

viii. Coleman, B. (2002). The impact of group lending in northeast Thailand. Journal of Development Economics., 60: $105-42$.

ix. Creswell, J. (2009). Research Design, Quantitative, Qualitative and Mixed Method Approaches. California: Sage Publications Ltd.

x. Dichter, S. (2006). The worrisome state of the poor. Pennsylvania University Press,

xi. Pennsylvania

xii. Fields, P. (2000). Putting people first: Sociological variables in rural development. India: Andhra Pradesh, Sage Publication.

xiii. Ghana Statistical Service (GSS) (2010). Population and housing census. Accra, GSS.

xiv. Ghana Statistical Service (GSS). (2008). Ghana living standard survey. Accra: Ghana Statistical Service.

xv. Ghana Microfinance Institutions Network (GHAMFIN ). ((2003)). Census of Micro Credit NGOs, Community-Based Organizations and Self Help Groups in Ghana. Accra: GHAMFIN.

xvi. Joanna B. I . (2014). Doing your research project. London, Open University Press

xvii. Karikari, O. (2009) Characteristics and constraints of rabbit farming in rural areas.

xviii. Nairobi, University of Kenya Press.

xix. Karlan, D and Zinman, M. (2006). Teaching Entrepreneurship: Impact of Business Training on Microfinance Clients and Institutions. Retrieved on May 25th 2014 from http:/ / www.aida.econ.yale.edu/ karlan/ papers/ Teaching

xx. Littlefield, E. (2005). Is Microfinance an Effective Strategy to Reach the Millenium Development Goals? Kumarian: Bloomfield, CT.

xxi. Musonda, C. (2006). Microfinance and gender equality: Are we getting there? Lusaka: Christian Enterprise Trust of Zambia.

xxii. Owusu, G. (2007). The role of small towns in regional development and poverty reduction in Ghana. International Journal of Urban and Regional Research, Vol. 8 PP 55-75.

xxiii. Richard, V. (2007). Services for the poor: What work, why and where? Sri Lanka: Asian Development Bank.

xxiv. Rogaly, B. (1996). Perceptions of the Impact of Microfinance on Livelihood Security. Dublin: Kimmage Development Studies Centre.

xxv. Sowa, J.E. (2008). Do Government tools Influence Organizational Performance

xxvi. Views from the Frontline. Journal of Policy Studies Vol.56 (73) PP 76-89.

xxvii. Sundaresan, S. (2008). The Changing Landscape of Microfinance. Journal of Emerging Trends and Challenges of Microfinance, 1-24.

xxviii. Taiwo, J. N. (2012). The impact of microfinance on welfare and poverty. Ota: Covenant University Press. 
xxix. United Nations (UN). (2005.). Building Inclusive Financial Sectors to Achieve the Millennium. New York: United Nations Capital Development Fund, (UNCDF).

xxx. Wodon, Q. (2014). Do remittances reach households living in unfavourable. Evidence from the Republic of Yemen. Germany: University of Munich.

xxxi. World Health Organization (WHO). (2008). Global database on child growth and malnutrition. India: Adventure Works Press.

xxxii. Yaro, J. A. (ed). (2013). Rural Development in northern Ghana. New York: Nova Science Publishers,.

xxxiii. Yankson, P. W. (2008). Decentralisation and Poverty Reduction in the Gomoa District of Ghana. Norwegian Journal of Geography (NGT), Vol. 62 (3) pp230.

xxxiv. Yamane, T. (1967). Statistics: An Introductory Analysis, 2nd Edition, New. New York: Harper and Row. 